J. Product. \& Dev., 23(3): $679-690$ (2018)

\title{
EFFECT OF PLANT DENSITY ON GROWTH AND YIELD OF TWO GARLIC CULTIVARS UNDER SOHAG CLIMATIC CONDITIONS
}

\author{
A. S. Badawy and H. E. Mohamed \\ Hort. Res. Inst. A.R.C. Giza, Egypt
}

\section{ABSTRACT}

One field experiment was carried out during the two successive winter seasons of 2014/2015 and 2015/2016 at a Private Farm at Sohag Governorate, to study the effect of two cultivars (Balady and Sids 40) and three plant densities (one, two and three rows in ridge) on growth, yield and bulb quality of garlic, these treatments were arranged in a split plot design with three replicates, garlic cultivars were arranged in the main plot, while plant densities were arranged in the sub plot.

The obtained results could be summarized as follows: The interaction between Balady cultivar and planting in one row/ ridge recorded the tallest plants in both seasons. The percentages of dry matter of both leaves/plant and bulb, both bulb diameter and weight as well as clove weight were the highest with the interaction between Sids 40 and planting in one row/ ridge in both seasons. While, the highest total fresh (15.96 and 14.03 ton/fed.) and cured yield (10.02 and 8.80 ton/fed.) were obtained with the interaction between Sids 40 cultivar and planting in three rows/ ridge in the $1^{\text {st }}$ and $2^{\text {nd }}$ seasons, respectively, this treatment recorded relative increases in total fresh yield /fed. were about 56.31 and $58.89 \%$ and total cured yield /fed were about 40.33 and $43.08 \%$ over the interaction between Balady cultivar and planting in one row/ ridge. in the $1^{\text {st }}$ and $2^{\text {nd }}$ seasons, respectively.

Conclusively, under the conditions of this study, cultivated garlic $c v$ Sids 40 in three rows / ridge for the best interaction treatment for increasing the productivity of garlic yield under Sohag climatic conditions.

Key words: Garlic, plant density, plant growth, yield. 


\section{INTRODUCTION}

Garlic (Allium sativum L.) is one of the most important and widely consumed bulbous spice crops belongs to the family Alliaceae. West Asia and Mediterranean region is considered to be the center of origin of garlic. It is cultivated throughout India for its bulb which forms an integral part of Indian culinary. The bulb can be consumed as spice or condiment in the form of garlic paste, pickle, chutney, curried vegetables, curry powders and meat preparation, etc. value added products of garlic are represented by garlic powder. It is the second most widely cultivated crop after onion (Hamma et al., 2013).

There were a significant differences between garlic cultivars concerning plant growth, yield and its components as well as bulb quality (Halim 2000, Azad 2002, Islam et al., 2004, Rahman et al., 2005, Mohsen 2012, Youssef and Tony 2014, Zaki et al., 2014, Hassan 2015 and Hassan et al. 2016 and Usman et al. (2016).

They concluded that there were a different characters between the cultivars of garlic.

For increasing garlic production there is a need to check the optimum density of garlic (Khodadadi and Nosrati, 2012). Planting density decrease competition for light, water and nutrient in plants. Without wastage optimum plant population ensures effective use of available cropland (Geremew et al., 2010).

Plant growth, yield and bulb quality had affected by plant densities (Abubakar, 2001, Jamroz et al., (2001), Castellanos et al., 2004, Singh and Singh 2004, Dawar et al., 2005, Sirohi 2005, Adekpe et al., 2007, Gautam et al., 2007, Kilgori et al., 2007, Rekowska and Skupien (2008) Fikreyohannes et al. 2008, El-Shal et al. 2011 and Nagina et al. 2017).

Therefore, the aim of the present experiment was to determine the suitable plant density and best cultivar of garlic for increasing productivity and bulb quality of garlic under Sohag climatic conditions, Egypt . 


\section{MATERIALS AND METHODS}

One field experiment was carried out during the two successive winter seasons of 2014/2015 and 2015/2016 at a Private Farm at Sohag Governorate, Egypt to study the effect of two cultivars (Balady and Sids 40) and three plant densities (one, two and three rows in ridge) on growth, yield and bulb quality of garlic. The meteorological data according to Sohag meteorological station is listed in Table A.

Table (A). Average monthly temperature and relative humidity at Sohag during the tow studies seasons*:

\begin{tabular}{|c|c|c|c|c|c|c|}
\hline \multirow{3}{*}{ Sonth } & \multicolumn{3}{|c|}{$2014 / 2015$} & \multicolumn{3}{|c|}{$2015 / 2016$} \\
\hline & \multicolumn{2}{|c|}{$\begin{array}{c}\text { Temperature } \\
\text { C }^{\mathbf{0}}\end{array}$} & \multirow{2}{*}{$\begin{array}{c}\text { Relative } \\
\text { Humidity } \\
(\%)\end{array}$} & \multicolumn{2}{|c|}{$\begin{array}{c}\text { Temperature } \\
\text { C }^{\mathbf{0}}\end{array}$} & \multirow{2}{*}{$\begin{array}{c}\text { Relative } \\
\text { Humidity } \\
(\%)\end{array}$} \\
\hline & Max. & Min. & & Max. & Min. & \\
\hline September & 35.7 & 24.2 & 32.8 & 38.3 & 23.6 & 37.5 \\
\hline October & 30.9 & 16.7 & 35.5 & 32.7 & 19.4 & 50.5 \\
\hline November & 26.2 & 21.1 & 44.3 & 25.2 & 21.7 & 58.8 \\
\hline December & 22.8 & 8.3 & 47.1 & 20.2 & 7.1 & 62.9 \\
\hline January & 20.1 & 5.2 & 43.3 & 18.2 & 5.0 & 59.9 \\
\hline February & 22.7 & 7.5 & 37.7 & 24.4 & 8.2 & 50.8 \\
\hline March & 26.8 & 11.6 & 33.4 & 27.8 & 13.2 & 40.3 \\
\hline April & 29.3 & 14.2 & 24.0 & 34.7 & 17.1 & 31.9 \\
\hline May & 34.9 & 19.5 & 26.1 & 35.9 & 20.0 & 27.5 \\
\hline
\end{tabular}

(*) Source: Sohag meteorological station.

These treatments were arranged in a split plot design with three replicates, garlic cultivars were arranged in the main plot, while plant densities were arranged in the sub plot.

The experimental area was $10.5 \mathrm{~m}^{2}$ (1/400 fed.) it was consisted of 5 ridges, $60 \mathrm{~cm}$ width and $3.5 \mathrm{~m}$ length.

Garlic cloves were selected for uniformity in shape and size and were planted of October $11^{\text {th }}$ and $15^{\text {th }}$ in 2014/2015 and 2015/2016 seasons, respectively. Cloves were planted with top of ridges at $10 \mathrm{~cm}$ apart. 
All experimental units were fertilized with 120, 60 and $48 \mathrm{~kg} / \mathrm{fed} \mathrm{N}, \mathrm{P}$ and $\mathrm{K}$ in the form of ammonium nitrate $(33.5 \%)$, super phosphate $(15.5 \%$ $\left.\mathrm{P}_{2} \mathrm{O}_{5}\right)$ and potassium sulphate $\left(48 \% \quad \mathrm{~K}_{2} \mathrm{O}\right)$, respectively. These fertilizers were added on three equal portions at 30,60 and 90 days after planting.

The normal cultural practices have been followed according to the usual methods being adapted for garlic crop.

A month before harvest, ten plants were randomly taken from each plot to determine plant height, number of leaves/plant, dry matter of leaves and bulb percentage its were determined by drying $100 \mathrm{~g}$ of grated leaves tissues and bulbs at $105{ }^{\circ} \mathrm{C}$ till constant weight, and then DM (\%) was calculated.

Garlic plants were harvested on April $3^{\text {rd }}$ and $4^{\text {th }}$ in the first and second seasons, respectively, and fresh yield per plot was recorded and converted to fresh yield (ton/fed.).

Then, the harvested plants were left in the field to cured for 15 days in the two seasons, then the cured yield (ton/fed.) was determined. After that, ten plants from each sub-plot were randomly taken to Bulb diameter with the help of Verniercalliper, bulb and clove weights were measured with the help of electric balance.

\section{Statistical analysis}

Statistical analysis was conducted for all collected data. The analysis of variance was calculated according to Steel et al. (1997) and means separation were done according to LSD at 0.05 probability level.

\section{RESULTS AND DISCUSSION}

\section{Effect of garlic cultivars}

Data in Table 1 indicated that, there were significant differences between the two garlic cultivars regarding plant growth, yield and bulb quality in most cases in both seasons. Balady cultivar gave the tallest plants than Sids 40 in both seasons. While Sids 40 gave the highest values of dry matter of leaves and bulb percentage, total fresh yield and weight of clove in both seasons, cured yield and bulb weight in the $1^{\text {st }}$ season only. On the other side, three were no significant differences between two 
Table (1): Effect of garlic cultivars on plant growth, yield and bulb quality during 2014/2015 and 2015/2016 seasons

\begin{tabular}{|c|c|c|c|c|c|c|c|c|c|}
\hline \multirow[t]{2}{*}{ Traits } & \multicolumn{3}{|c|}{ Plant growth } & \multicolumn{3}{|c|}{ Yield (ton/fed) } & \multicolumn{3}{|c|}{ Bulb quality } \\
\hline & $\begin{array}{c}\text { Plant } \\
\text { height } \\
(\mathrm{cm})\end{array}$ & $\begin{array}{c}\text { No. of } \\
\text { leaves/ } \\
\text { plant }\end{array}$ & $\begin{array}{c}\text { Dry } \\
\text { matter } \\
\text { leaves } \\
\% \\
\end{array}$ & $\begin{array}{c}\text { Dry } \\
\text { matter } \\
\text { bulbs } \\
\%\end{array}$ & $\begin{array}{c}\text { Fresh } \\
\text { yield }\end{array}$ & $\begin{array}{c}\text { Cured } \\
\text { yield }\end{array}$ & $\begin{array}{c}\text { Bulb } \\
\text { diameter } \\
(\mathrm{cm})\end{array}$ & $\begin{array}{c}\text { Bulb } \\
\text { weight } \\
\text { (g) }\end{array}$ & $\begin{array}{c}\text { Weight } \\
\text { of } \\
\text { cloves } \\
(\mathrm{g})\end{array}$ \\
\hline Cultivars & \multicolumn{9}{|c|}{ 2014/2015 season } \\
\hline Balady & 89.7. & 11.1 & 13.7 & 21.6 & 12.70 & 8.61 & 4.9 & 49.9 & 1.8 \\
\hline Sids40 & 65.1 & 11.9 & 18.3 & 26.6 & 14.24 & 9.23 & 5.2 & 54.1 & 3.5 \\
\hline LSD $_{0.05}$ & 5.3 & NS & 1.7 & 2.1 & 1.06 & 0.42 & NS & 3.2 & 0.9 \\
\hline & \multicolumn{9}{|c|}{ 2015/2016 season } \\
\hline Balady & 82.3 & 10.9 & 12.0 & 18.7 & 11.19 & 7.33 & 4.5 & 43.7 & 1.4 \\
\hline Sids40 & 61.2 & 12.6 & 16.2 & 24.6 & 11.78 & 7.65 & 4.9 & 45.2 & 3.0 \\
\hline LSD $_{0.05}$ & 3.9 & NS & 1.3 & 1.7 & 0.45 & NS & NS & NS & 0.4 \\
\hline
\end{tabular}

cultivars concerning number of leaves / plant and bulb diameter in both seasons, cured yield and bulb weight in the $2^{\text {nd }}$ season .

The relative increases in total fresh yield /fed. were about 12.12 and $5.27 \%$ and total cured yield /fed were about 7.20 and $4.36 \%$ for Sids 40 cultivar than Balady cultivar in the $1^{\text {st }}$ and $2^{\text {nd }}$ seasons, respectively.

The differences between garlic cultivars could be attributed to the genetic differences between cultivars. These results are in agreement with (Halim 2000, Azad 2002, Islam et al., 2004, Rahman et al., 2005, Mohsen 2012, Youssef and Tony 2014, Zaki et al., 2014, Hassan 2015 and Hassan et al. 2016 and Usman et al., 2016). They concluded that there were a different characters between the cultivars of garlic.

\section{Effect of plant density}

Data in Table (2) show that, plant growth, yield and bulb quality of garlic grown under Sohag conditions had affected by plant density in both seasons.

Planting of garlic in one row/ ridge had significantly increased plant growth such as plant height the percentages of dry matter of both leaves and bulb, both bulb diameter and weight as well as clove weight than other densities (two or three rows/ ridge) in both seasons. While, garlic planting in three rows /ridge recorded the highest values of both total fresh and curd yield/fed. than other densities in both seasons. Plant densities did not 
Table (2): Effect of plant density on plant growth, yield and bulb quality during 2014/2015 and 2015/2016 seasons

\begin{tabular}{|c|c|c|c|c|c|c|c|c|c|}
\hline \multirow[t]{2}{*}{ Traits } & \multicolumn{4}{|c|}{ Plant growth } & \multicolumn{2}{|c|}{ Yield (ton/fed) } & \multicolumn{3}{|c|}{ Bulb quality } \\
\hline & $\begin{array}{l}\text { Plant } \\
\text { heigh } \\
t(\mathrm{~cm})\end{array}$ & $\begin{array}{c}\begin{array}{c}\text { No. of } \\
\text { leaves } \\
/ \\
\text { plant }\end{array} \\
\end{array}$ & $\begin{array}{c}\text { Dry } \\
\text { matter } \\
\text { leaves } \\
\%\end{array}$ & $\begin{array}{l}\text { Dry } \\
\text { matter } \\
\text { bulbs } \\
\%\end{array}$ & $\begin{array}{c}\text { Fresh } \\
\text { yield }\end{array}$ & $\begin{array}{c}\text { Cured } \\
\text { yield }\end{array}$ & $\begin{array}{c}\text { Bulb } \\
\text { diameter } \\
(\mathbf{c m})\end{array}$ & $\begin{array}{c}\text { Bulb } \\
\text { weight } \\
\text { (g) }\end{array}$ & $\begin{array}{l}\text { Weight } \\
\text { of } \\
\text { cloves } \\
\text { (g) }\end{array}$ \\
\hline Density & \multicolumn{9}{|c|}{ 2014/2015 season } \\
\hline Irow & 82.5 & 12.2 & 17.8 & 26.5 & 11.07 & 7.62 & 6.1 & 59.6 & 3.3 \\
\hline 2 rows & 77.3 & 11.6 & 16.1 & 24.5 & 14.08 & 9.20 & 5.2 & 48.1 & 2.6 \\
\hline 3 rows & 72.5 & 10.8 & 14.1 & 21.4 & 15.34 & 9.94 & 4.0 & 35.6 & 2.3 \\
\hline $\operatorname{LSD}_{0.0}$ & 3.1 & NS & 1.3 & 1.8 & 1.32 & 0.52 & 0.4 & 5.6 & 0.5 \\
\hline & \multicolumn{9}{|c|}{ 2015/2016 season } \\
\hline 1 row & 76.8 & 12.7 & 15.7 & 24.2 & 8.94 & 6.24 & 5.6 & 62.3 & 2.8 \\
\hline 2 rows & 71.4 & 12.4 & 14.7 & 22.4 & 11.97 & 7.80 & 4.9 & 40.8 & 2.2 \\
\hline 3 rows & 67.2 & 10.3 & 12.0 & 18.5 & 13.52 & 8.45 & 3.7 & 30.4 & 1.8 \\
\hline $\operatorname{LSD}_{0.0}$ & 2.1 & NS & 1.1 & 1.5 & 0.73 & 0.26 & 0.2 & 5.1 & 0.3 \\
\hline
\end{tabular}

reflect any significant effect on number of leaves/ plant in both seasons. On the other side, planting of garlic in two rows/ ridge gave the intermediate values of plant growth, yield and bulb quality between planting in one or three rows/ ridge in both seasons.

The relative increases in total fresh yield /fed. were about 38.57 and $51.23 \%$ and total cured yield /fed. were about 30.44 and $35.41 \%$ for planting in three rows/ ridge than planting in one row/ ridge in the $1^{\text {st }}$ and $2^{\text {nd }}$ seasons, respectively.

The reduction in growth characters of plants in the case of increased plant density may be due to increased competition among crop plants and the struggle in an enforced sharing of light, nutrients and water supplies as well as space of the surrounding media. (Ara et al., 2007).

Light is critical source of photosynthesis for plant growth, large spaced plant gets proper light intensity and nutrient as compare to the small spaced plant that's why leaf area of wider spaced plant is more leaf length increase as we increase plant spacing, plants spread more and leaf area increases due to moisture availability, nutrients and additional light intensity all these lead to more increased in plant growth. More bulb diameter, weight and increased for weight of cloves obtained from wider spacing may be due to vigorous plant (Biru, 2015). 
The productivity of unit area greatly influenced by the number of plants in units area. However, total yield is associated strongly by the number of growing plants in unit area, on the other side, the yield quality such as bulb diameter and weight response negatively (Rekowska and Skupien, 2008). These results are in agreement with the results of Rahman and Talukdar (2003), Castellanos et al. (2004), Singh and Singh (2004), Dawar et al. (2005), Sirohi (2005), Adekpe et al., (2007), Gautam et al. (2007), Kilgori et al, (2007), Rekowska and Skupien (2008) and Fikreyohannes et al. (2008).

\section{Effect of the interaction between cultivars and plant densities}

The interactions between garlic cultivars and plant densities had significant effect on plant growth, yield and bulb quality of garlic under Sohag conditions in both seasons, except number of leaves / plant in both seasons.

The interaction between Balady cultivar and planting in one row/ ridge recorded the tallest plants $(95.2 \mathrm{~cm}$ and $90.3 \mathrm{~cm})$ in the $1^{\text {st }}$ and $2^{\text {nd }}$ seasons respectively. The percentages of dry matter of both leaves/plant and bulb, both bulb diameter and weight as well as clove weight were the highest with the interaction between Sids 40 and planting in one row/ ridge in both seasons. While the highest total fresh (15.96 and 14.03 ton/fed.) and cured yield ( 10.02 and 8.80 ton/fed.) were obtained with the interaction between Sids 40 cultivar and planting in three rows/ ridge in the $1^{\text {st }}$ and $2^{\text {nd }}$ seasons, respectively.

The relative increases in total fresh yield /fed. were about 56.31 and $58.89 \%$ and total cured yield /fed were about 40.33 and $43.08 \%$ for the interaction between Sids 40 cultivar and planting in three rows/ ridge than the interaction between Balady cultivar and planting in one row/ ridge in the $1^{\text {st }}$ and $2^{\text {nd }}$ seasons, respectively.

These results are in agreement with those reported with Alam et al. (2010) and Abdalla et al. (2011) found that there were significant differences with the interaction between garlic cultivars and plant densities. 
Table (3): Effect of the interaction between garlic cultivars and plant density on plant growth, yield and bulb quality during 2014/2015 and 2015/2016 seasons

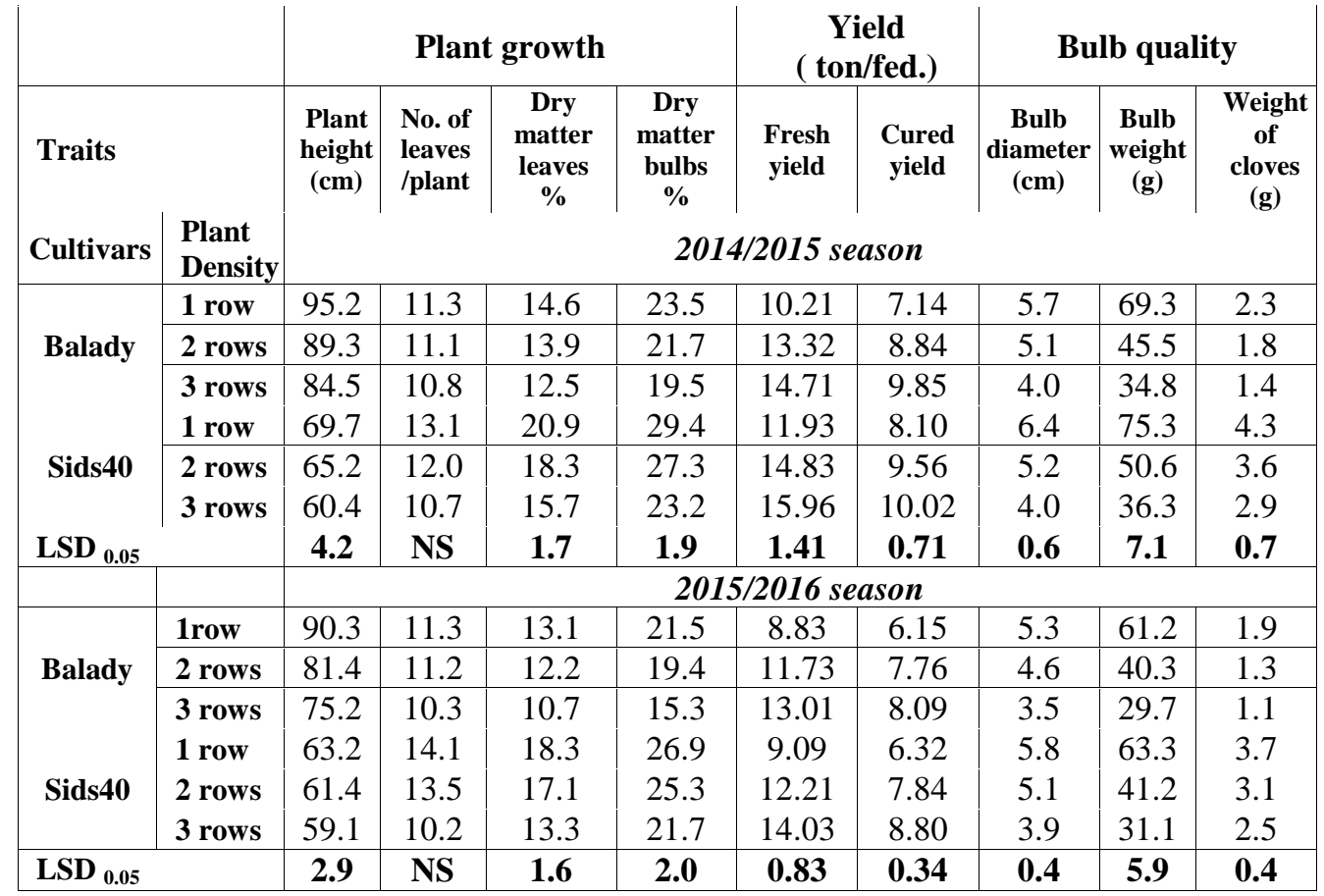

Conclusively, under the conditions of this study, cultivated garlic cv sids 40 in three rows / ridge for the best interaction treatment for increasing the productivity of garlic yield under Sohag climatic conditions.

\section{REFERENCES}

Abdalla M.M. A. , M. H. Aboul-Nasr, A. K. Metwaly and Shreen H. Ali (2011). Growth and Yield of Fifteen Garlic Ecotypes. Assiut J. Agric. Sci., 36 (5): 52-65.

Abubakar A. (2001). Growth indices and bulb yield of garlic (Allium sativum L.) as affected by inter and intrarow spacing. (Unpublished) B.Sc. Project, Department of Agronomy, ABU Zaria. 
Adekpe, D.I., J.A.Y. Shebayan, U.F. Chiezey and S. Miko (2007). yield responses of garlic (Allium sativum L.) to oxadiazon, date of planting and intra-row spacing under irrigation at kadawa, Nigeria. Crop Protection, 26 (12):1785-1789.

Alam M.S., M.A. Rahim, M.A.H. Bhuyan , P.W. Simon and M.A. Malek (2010). Effect of spacing on growth and yield of two lines of garlic under dry land condition. J. Agro for. Environ., 4 (2): 151154.

Ara N., M.K. Bashar and S. Kakon (2007). Effect of spacing and pruning on growth and yield of tomato. Inter. J. Sustainable Crop Production, 2(3): 35-39.

Azad, A. K. (2002). Effect of planting time and clove size on the growth and yield of four garlic germplasm. M S Thesis, Hort Dept. BAU, Mymensingh. pp. 32-35.

Biru F.N. (2015). Effect of spacing and nitrogen fertilizer on the yield and yield component of shallot (Allium ascalonium L.). J. Biology, 5(11): 83-91.

Castellanos, J. Z., A. Gonzalez, A. Sanchez and A.A. Gardea (2004). Garlic productivity and profitability as affected by seed clove size, planting density and planting method. Hort. Sci. , 39 (6): 1272-1277.

Dawar, M.U.D., S.A. Hussain and S. Muhammad (2005). Effect of planting density and nitrogen levels on the growth and yield of garlic. Sawrhad J. Agric. , 21 (4): 577-582.

El-Shal, Z. S., E. A. Radwan, M. F. Zaki and Fatma A. Rizk (2011). The productivity of garlic plant (Allium sativum L.) as affected by plant densities and NPK application. J. Plant Production, Mansoura Univ., 2 (7): 865 - 875.

Fikreyohannes, G., W. Kebede, D. Nigussie and T. Akhilesh (2008). Effects of clove size and plant density on the bulb yield and yield components of Ethiopian garlic (Allium sativum L.). Pant Agar J. Res., 6 (2): 234-238.

Gautam, P.K.S.; I.N. Shukla; J.P. Singh and S. Kumar (2007). Studies on effect on varying plant density, planting and irrigation time on growth and yield of garlic (Allium sativum L.). Progressive-Agric., 7(12): 167-168. 
Geremew A, A. Teshome, T, Kasaye and C. Amenti (2010). Effect of intra-row spacing on yield of three onion (Allium cepa L.) varieties at Adami Tulu Agricultural Research Center (Mid Rift valley of Ethiopia). J. Hort. Forestry, 2(1):7-11.

Halim, A. (2000). Effects of mulches on the growth and yield of some garlic germplasms. M. S. Thesis, Dept. Hort., BAU, Mymensingh. p. 103.

Hamma I.L., U. Ibrahim and A. B. Mohammed (2013). Growth, yield and economic performance of garlic (Allium sativum L.) as influenced by farm yard manure and spacing in Zaria. Nigeria. J. Agric. Economics and Develop., 2(1):1-5.

Hassan G.H, M.A. El-Shal, KH.A. Soliman , I.M Ghoneim (2016). Effect of planting dates and periods of curing on quantitative, qualitative characteristics and storage ability of two garlic cultivars. J. Agric. Res. Kafr El-Sheikh Univ. 42(3):401-414.

Hassan. A. H. (2015). Improving growth and productivity of two garlic cultivars (Allium sativum L.) grown under sandy soil conditions. Middle East J. Agric. Res., 4(2): 332-346.

Islam, M. J., Islam, M. A., Tania, S.A. Saha, S. R. Alam, M.S. and. M. K Hasan (2004). Performance evaluation of some garlic genotype in Bangladesh. Asian J. Plant Sci., 3 (1): 1416.

Jamroz, M., N. Ishtiaq, N. Naeem, B. Muhammad and J. Iqbal (2001). Effect of different planting dates and spacing on growth and yield of garlic $c v$. Bianco. J. Bio. Sci., 1 (4): 206-208.

Khodadadi A. and M.A.E. Nosrati (2012). Effect of Sowing Date and Planting Density on Yield and Yield Components of White Garlic of Hamadan. Seed and Plant Production J. 27(4): 491-500.

Kilgori, M.J.; M.D. Magaji and A.I. Yakubu (2007). Effect of plant spacing and date of planting on yield of two garlic (Allium sativum L.) cultivars in Sokoto, Nigeria. Amer. Eurasian J. Agric. Environ. Sci., 2 (2): 153-157. 
Mohsen, A. A.M. (2012). Response of garlic plant to nitrogen, phosphorus, potassium and some biofertilizer levels under sandy soil conditions. Ph.D. These, Fac. Agric. Zagazig Univeristy.

Nagina, M., H. Muhammad, J.A. Muhammad, K. Nadra, H. Nasir and H., Babar (2017). Effect of planting density on growth, yield and quality of Garlic at Rawalakot, Azad Kashmir. Inter. J. Agron. Agric. Res., 10 (1): 42-51.

Rahman A.K.M. and M.P. Talukdar (2003). Influence of date of planting and plant spacing on the growth and yield or garlic. Bangladesh J. Agric., 11:19-26.

Rahman, M. S., M. Islam, M. S. Haque and M. A. Karim (2005). Effects of planting date and gibberellic acid on the growth and yield of garlic (Allium sativum L.). Asian J. Plant Sci., 3(3): 344-352.

Rekowska, E. and K. Skupien (2008). Estimation of yield and chemical composition of winter garlic grown for bunch-harvest. J. Central European Agric., 9(4): 711-714.

Singh, S.K. and R.K. Singh (2004). Interaction effect of nitrogen, planting time and spacing on the performance of garlic, (Allium sativum $\mathrm{cv}$. Yamuna Safed (G-1). Biochemical and Cellular Archives, 4 (2): 123-128.

Sirohi, H.S. (2005): Effect of time of planting and spacing on yield of garlic (Allium sativum L.). Haryana J. of Hort. Sci., 34 (1/2): 191.

Steel R.G.D., J.H. Terrie and M.A. Boston (1997). Principles and Producers of Statistics. 2nd Edition. Mc Graw Hill, New York pp.636.

Usman, M. G., A. S. Fagam, R. U. Dayi and Z. Isah (2016). Phenotypic response of two garlic varieties to different nitrogen fertilization grown under irrigation in Sudan Savannah ecological zone of Nigeria. Inter. J. Agron., (9): 1-10.

Youssef N. S. and H. S.H. Tony (2014). Influence of Different Planting Date on the Performance of New Garlic Genotypes Grown Under El-Minia Governorate Conditions. Nature Sci., 12(5):112-119.

Zaki, H.E.M. , H.S.H Toney and R.M Abd Elraouf (2014). Response of two garlic cultivars (Allium sativum L.) to inorganic and organic fertilization. Nature and Sci., (12): 52-60. 


\section{تاثير الكثافة النباتية علي نمو وانتاج صنفين من الثوم تحت الظروف المناخية لسوهاج}

$$
\begin{aligned}
& \text { عبدالحكيم شوقي بلوي - حسن البلري محمد }
\end{aligned}
$$

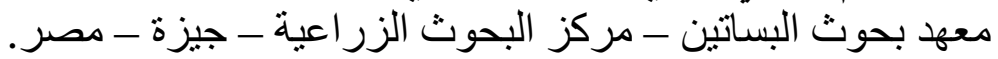

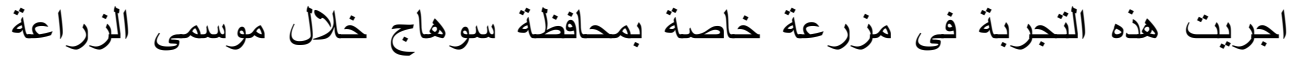

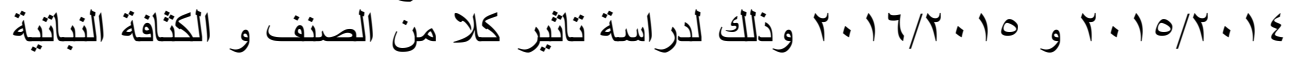

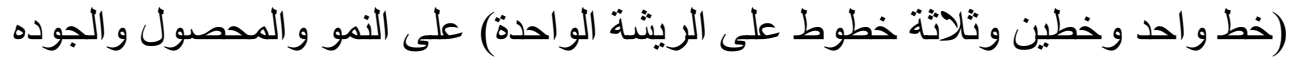

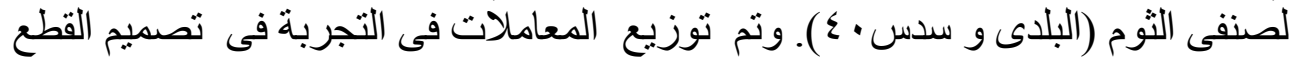

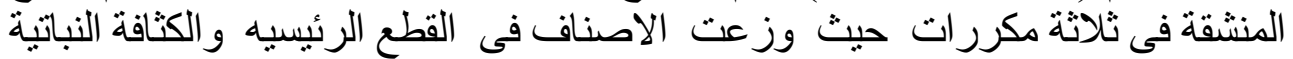

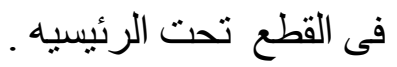

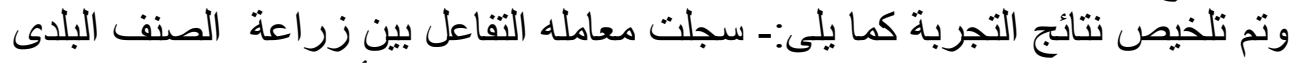

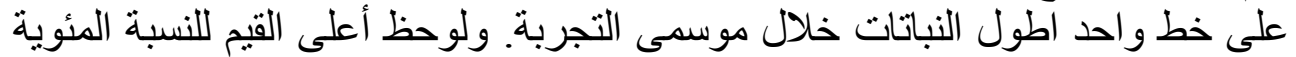

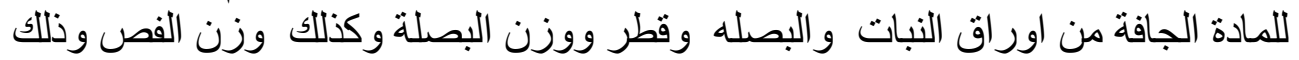

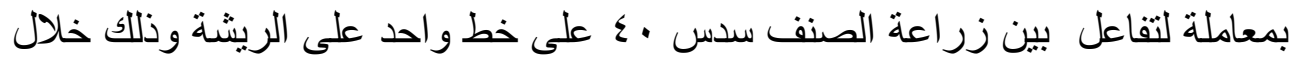

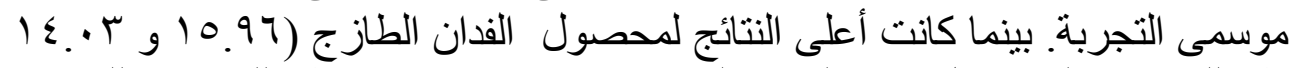

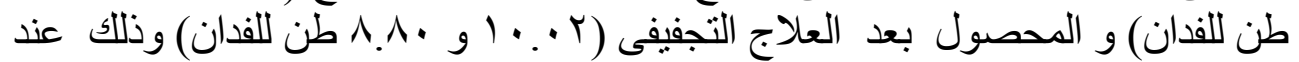

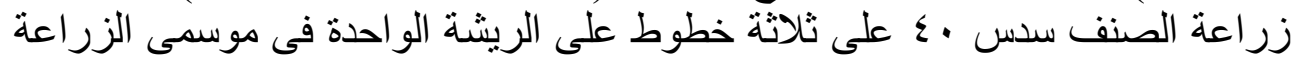

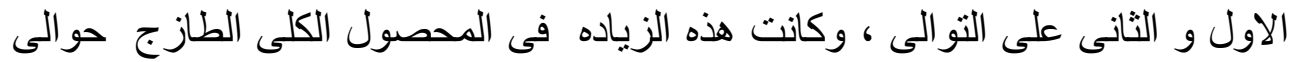

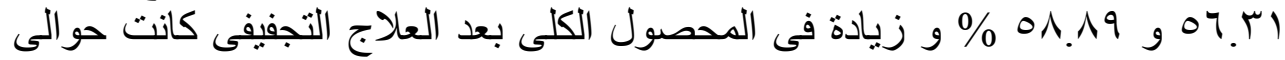

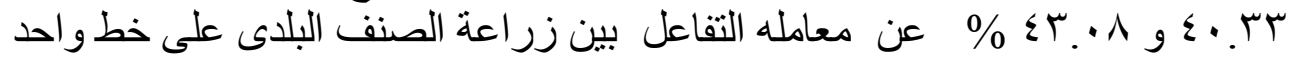

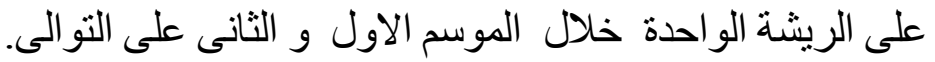

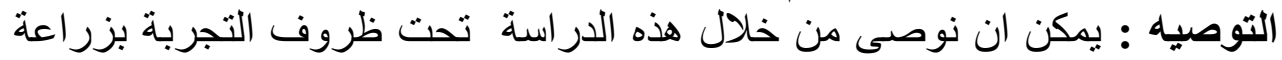
الصنف سدس • ع على ثلاثة خطوط على على الريشة الو احدة وذللك لزئ لزيادة انتاجية الثوم تحت الظروف المناخيه لسوهاج. تلاثة خطوط 